\title{
Effects of Cultured Adrenal Chromaffin Cell Implants on Hindlimb Reflexes of the 6-OHDA Lesioned Rat
}

\author{
Bruce E. Pulford, Andrea R. Mihajlov, Howard O. Nornes and L. Ray Whalen \\ Department of Anatomy and Neurobiology, Colorado State University, Ft. Collins, CO 80523, USA
}

\section{SUMMARY}

The effects of implantation of cultured adrenal medullary cells on the recovery of neurotransmitter specific reflex activity were studied in the rat spinal cord using electrophysiological testing methods. Cell suspensions of cultured neonatal adrenal medullary chromaffin (AM) cells (which produce catecholamines), or Schwann (Sc) cells (controls) were implanted into the lumbar region of the spinal cord 2 weeks after catecholamine (CA) denervation by intracisternal injection of 6hydroxydopamine (6-OHDA). All cells were taken from 7 day neonates and cultured for 10 days in the presence of nerve growth factor (NGF). Three months after implantation, the extent of implant-associated recovery of reflex activity was determined by measuring electromyogram (EMG) activity and force associated with the long latency component of the hindlimb withdrawal reflex (which is $\mathrm{CA}$ modulated). After the electrophysiological testing, rats were anesthetized, and the spinal cords were rapidly removed and frozen. Spinal cords were sectioned longitudinally, and implanted cells were visualized using glyoxylic acid techniques. Labelled sections were examined to determine cell survival. Results indicate that 1 ) chromaffin cells survive for 3 months in the segments of the cord into which they have been implanted and 2) rats implanted with $\mathbf{A M}$ cells have significantly more forceful withdrawal reflexes than those that received Sc cells or received no implant after lesioning.

\section{Reprint address:}

Bruce E. Pulford

Department of Anatomy and Neurobiology

Colorado State University

Ft. Collins, CO 80523, USA

\section{KEY WORDS}

transplant, catecholamines, chromaffin cells, Schwann cells, culture, withdrawal reflex, spinal cord

\section{INTRODUCTION}

The mammalian spinal cord can be viewed both as a pathway for signals between the brain and body and as a semi-independent system consisting of an array of interconnected components controlling reflex and patterned movements. The reflex and pattern generator pathways are not independent, as they receive suprasegmental input from various regions of the brain to initiate and regulate voluntary movements. Damage to the spinal cord at any level can disrupt input to these reflex pathways, resulting in functional deficits. Attempts to reconnect proximal and distal sections of spinal cord at the point of injury have been unsuccessful. Bridges composed of peripheral nerves $/ 2,32,40 /$ or collagen matrix /26/ inserted into lesioned spinal cord have not resulted in the formation of functional connections $/ 1 /$. Hormones $/ 21,29 /$, growth factors $/ 1 /$, enzymes $/ 23 /$, steroids $/ 9,10 /$ and electric fields $/ 8,20 /$ have been used in attempts to enhance regeneration, but the effects on neural regrowth were minimal. Recently, antibodies to inhibitory proteins found in myelin have been tested for their effects on regeneration in vivo, and found to be partially successful in fostering regeneration /44/. Other investigators have sought to replace lesioned descending tracts or cell types within the spinal cord by implanting cell suspensions or pieces of neural or non-neural tissue. Embryonic spinal cord $/ 6,47 /$, cerebral cortex $/ 27 /$, medullary and mesencephalic raphe neurons $/ 25 /$, locus ceruleus $/ 11,15,35,38 /$, and neonatal chromaffin cells $/ 42,43 /$ have been implanted into the mammalian spinal cord with 
some success in the survival, differentiation, and growth of the implants, but with no success in recovery of function.

In previous studies $/ 11,35 /$ the functional effects of spinal implants of fetal locus ceruleus tissue, a potential. source of the catecholamine noradrenaline (NA), on the hindlimb withdrawal reflex in 6hydroxydopamine (6-OHDA) lesioned rats were examined. Advantages of using the withdrawal (flexion) reflex is that it is a relative simple system and has been studied extensively $/ 4,7,12,33,34 /$. Flexor reflex afferent fibers (FRAs), which include group II and III muscle afferents, joint afferents, and low and high threshold cutaneous afferents, converge on interneurons within the spinal cord /33/ (Figure 1). Lundberg $/ 33 /$ postulates that these fibers are capable of evoking the withdrawal reflex by activating neuronal networks that excite flexor alpha motoneurons in the ventral horn of the cord. This reflex is modulated by NA fibers from the locus ceruleus (brainstem) which synapse bilaterally in the spinal cord ventral horn /7/. Jankowska et al. /30/ found that electrical stimulation of the FRAs prior to administration of L-3-4-dihydroxyphenylalanine (L-DOPA) in spinal animals elicits a low threshold, short latency to onset response from the biceps femoris muscle (short latency component SLC). In this case, the postulated pathway A (Figure 1) is involved in the reflex. L-DOPA inhibits this pathway by stimulating the release of NA from ceruleospinal fibers within the cord $/ 30,31 /$. Inhibition of pathway A disinhibits the postulated pathway B. A short train of stimuli given to the FRAs, after pathway A inhibition via an injection of L-DOPA, evokes a large amplitude discharge in flexor motoneurons having both a long latency to onset and long duration of evoked muscle activity (long latency component - LLC). Monoamine oxidase inhibitors, such as pargyline, produce a 10fold potentiation of the L-DOPA effects /3/. Anden $13 /$ has also shown that alpha-adrenergic receptor blockers, such as phenoxybenzamine and phentolamine, are capable of blocking the L-DOPA effects on the withdrawal reflex. The protocol developed by Moorman et al. $135 /$ for testing the withdrawal reflex allows precise measurements of the force and myoelectric activity produced during withdrawal. This method also allows relatively easy

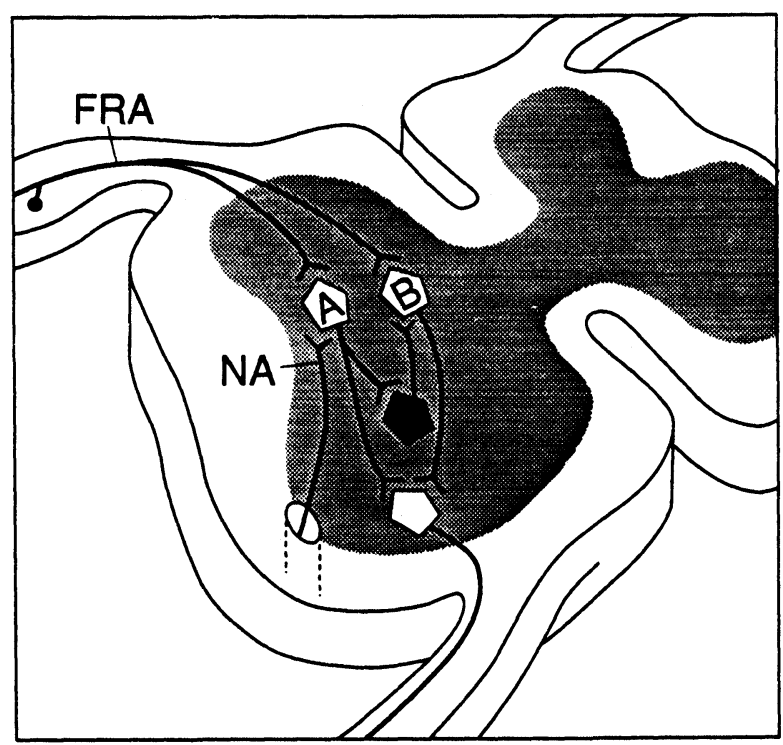

Fig. 1: Cross section of spinal cord showing proposed excitatory pathways between flexor reflex afferents (FRAs) and motoneurons. Stimulation of FRAs in the absence of L-DOPA (acute spinal animal) activates pathway $\mathrm{A}$, which is responsible for the short latency effect. The black interneuron, which may represent a chain of interneurons, is inhibitory. In the presence of L-DOPA, pathway A is inhibited by noradrenaline (NA) released by noradrenergic fibers from the locus ceruleus. This disinhibits pathway $B$, which is responsible for the long latency, large amplitude discharge in flexor motor neurons. (Adapted from Jankowska et al., $130 /$.

pharmacological manipulation of the neurons involved in the reflex pathway.

A significant increase in the force of the withdrawal reflex was noted by Moorman in 6OHDA lesioned rats that received fetal locus ceruleus implants when compared to lesioned controls $/ 35 /$. The level of force was found to be correlated to the number of catecholamineproducing implanted cells. The present study is a continuation of this work. We tested the possibility of using cultured neonatal adrenal medullary chromaffin (AM) cells to replace the 6-OHDA lesioned NA fibers in the spinal cord. There are certain advantages to using cultured cells for implants, including examination of the effect on 
physiology of a specific cell type and the potential clinical benefit of using autologous cell implants to aid neurologically impaired patients. Chromaffin cells were chosen for implantation because they are relatively easy to isolate and they release NA $/ 19,49 /$. When cultured AM cells are grown in the presence of nerve growth factor (NGF), most of the small (20-35 $\mu \mathrm{m}$ diameter) round cells assume neuronal characteristics, extending many fine processes, similar to those of small granule cells in sympathetic ganglia /49/. Both the round and neuronal-like cells exhibit intense CA fluorescence /19/. Growing isolated AM cells in the presence of NGF appears to select for NA producing cells /19/. Though there is evidence that NGF is present in the spinal cord of adult rats $/ 41,46 /$, it is not known whether the levels are sufficient to support isolated AM cells. Pieces of rat adrenal medulla and suspensions of isolated bovine chromaffin cells survive for up to 4 months in rats when placed or injected into the subarachnoid space of the spinal cord 143/. Previous work in our laboratories has also demonstrated that when whole adrenal medullas from neonatal rats are implanted into cavities produced in the lumbar spinal cord of mature rats, CA-containing cells are present up to 121 days after implantation (C. Jones, personal communication). However, few surviving cells extended processes, and those processes that were present were less than $40 \mu \mathrm{m}$ in length.

In the present study, AM cells were plated on cryostat sections of adult rat spinal cord to test their potential to grow and extend processes on spinal cord substrates in vitro. In in vivo experiments, ceruleospinal fibers in the spinal cord were destroyed by 6-OHDA. Chromaffin cells or Schwann cells ( $\mathrm{Sc}$ ), which were used as controls, were implanted into the region of the cord where fibers from the ceruleospinal tract normally converge onto neurons involved in the hindlimb withdrawal reflex. Three months post implantation, both the muscular force and electrical activity produced during reflex withdrawal were measured in the experimental rats and compared to force levels produced by control animals. In addition, we histochemically examined sections of implanted spinal cords stained for the presence of CAcontaining cells.

\section{MATERIALS AND METHODS}

\section{6-OHDA lesions}

Catecholamine-containing fibers within the spinal cord were destroyed in a total of 25 animals by injecting 6-OHDA into the cisterna magna. Female Sprague Dawley rats (12 weeks old) were anesthetized by injecting ketamine $(80 \mathrm{mg} / \mathrm{kg})$ and xylazine $(10 \mathrm{mg} / \mathrm{kg})$ intraperitoneally. An incision was made longitudinally beginning at the base of the skull and continuing caudad. The underlying muscles were separated to expose the atlantooccipital membrane. This membrane and the underlying dura and arachnoid membranes were then incised. Excess cerebrospinal fluid was absorbed before slightly enlarging the dural incision. The injection of 6-OHDA (Sigma, St. Louis, MO) was accomplished using a Hamilton syringe and a 30 ga needle (Hamilton Co., Reno, NV) secured in a micromanipulator. Twenty microliters of the solution (25 mg 6-OHDA in $2 \mathrm{ml}$ isotonic saline containing $0.2 \mathrm{mg} / \mathrm{ml}$ ascorbic acid) were injected over a period of 3-5 minutes into the subarachnoid space of the cisterna magna. The rat was placed on a surface that was inclined (rostral above caudal approximately $35^{\circ}$ ) during the 6-OHDA injection. After administration of the 6-OHDA, the rat was left in this position for 3 minutes before the wound was sutured closed.

\section{Cell culture techniques}

Adrenal glands were harvested from ten seven day-old rat pups using sterile technique. The capsule was removed from the gland, and the cortex was dissected away from the adrenal medulla, taking care to remove as much cortex as possible. The medulla was then cut into two or four pieces. The tissue was enzymatically dissociated with a solution of $0.25 \%$ collagenase (Worthington Biochemicals, Freehold, NJ) in Hanks' Basic Salt Solution (HBSS), (Gibco, Grand Island, NY) for one hour followed by $0.15 \%$ trypsin (Sigma) in HBSS for ten minutes. The trypsin was quenched by the addition of serum-containing growth media. DNase (Sigma) was added to this solution which was then incubated for $30 \mathrm{~min}$. The suspension was centrifuged and resuspended in high NGF (2.5S, 
Collaborative Biomedical, $40 \mathrm{ng} / \mathrm{ml}$ ) containing Dulbecco's Modified Eagle Medium (DMEM, Gibco) containing 10\% fetal calf serum (HyClone). The cells were mechanically dissociated by passing them through descending bore size fire-polished pipets. The AM cell suspension was plated onto collagen coated glass coverslip plates for seven to ten days before implantation.

Sciatic nerves from the same rat pups served as a source for Schwann cells. The nerves were cleaned of excess tissue, and the epineurium was carefully stripped off. The sciatic nerve pieces were enzymatically and mechanically dissociated using the same technique that was used for dissociating the adrenal medulla tissue. The sciatic nerve cell suspension pellet was resuspended in DMEM media with $10^{-5} \mathrm{M}$ cytosine arabinofuranoside (araC) (Sigma) to control fibroblast proliferation. The cells were plated on collagen coated plastic dishes, and the cytotoxic medium was used on days 1 and 3 .

Cells were removed from the culture dishes by a very careful light trypsinization $(0.06 \%$ trypsin in HBSS). Using this procedure, AM cells were detached leaving behind fibroblasts and Sc cells. Schwann cells were trypsinized in the same manner with care being taken to leave behind fibroblasts. A cell suspension was prepared, stored in the incubator $\left(8.5 \% \mathrm{CO}_{2}\right)$ during implantation, and removed only to fill the syringe. After all implants were performed, cell counts were made using trypan blue, and aliquots were removed with a syringe and plated on dishes to test for viability. Cell counts indicated that an average of 6600 cells were injected per animal (2200/site).

\section{Implantation}

Two weeks after the 6-OHDA lesion, cell suspensions of cultured neonatal AM cells $(n=7)$ or Sc cells $(n=6)$ were implanted into the lumbar region of the spinal cord using sterile technique. The rats were anesthetized via an i.p. injection of ketamine and xylazine. An incision was then made beginning just cranial to thoracic vertebra 11 (T11) and continuing to a point just caudal to lumbar vertebra 3 (L3). After the vertebrae in this region were surgically exposed, the interspinous and interarcuate ligaments between T12-T13, T13-L1, and L1-L2 were cut. The dura was carefully incised at these three locations, allowing access to the spinal cord. The rat was placed upon the raised platform of a stereotaxic unit, and a pair of Allis tissue forceps, attached to a micromanipulator, was clamped onto the spinous process of $\mathrm{T} 12$ to secure the vertebral column and prevent movement during injection. A Hamilton syringe $(10 \mu \mathrm{l})$ attached to a micromanipulator was used to inject $5 \mu$ of the cell suspension into the spinal cord at each of the 3 sites. The syringe needle ( $30 \mathrm{ga})$ was inserted completely through the left side of the cord, just lateral to the dorsal vein. The needle was then retracted 1-2 $\mathrm{mm}$, and injection of the cell suspension was made over a period of 2-3 minutes. One minute after injection, the needle was withdrawn over a 2-3 minute time span. This procedure was followed at each site, attaching the forceps to the spinous process of, successively, T13 and L1 prior to injection. During insertion of the needle, characteristic muscular twitching occurred, indicating that the needle was being inserted into the region of the spinal cord involved in the hindlimb withdrawal reflex. These reactions included twitching of the hypaxial muscles on the left side at T12-13, twitching of the muscles of the left thigh at T13-L1, and twitching of the digits of the left foot at L1-2. Following the third injection, the incision was closed using 6-0 suture (Ethicon) and wound clips. A sample of the remaining cell suspension was ejected through the needle and plated on cell culture dishes in order to verify the survivability and process outgrowth capability of the implanted cells. Another sample of the suspension was used for cell counts.

\section{Reflex testing}

Three months post-implantation, the spinal cord of the rat was transected, and the hindlimb withdrawal reflex was tested. Testing was done blindly, i.e. the tester did not know which experimental group the rat was from. Anesthesia was induced using halothane (inhaled) and maintained by inhaled metophane. An incision was made in the dorsocranial thoracic region and underlying epaxial muscles were separated to expose the T4-T6 thoracic vertebrae. A laminectomy was performed on T5. The dura was opened using iris scissors, and a suction pipette was 
used to remove a 1-2 mm section of the spinal cord. A small piece of gel-foam saturated with an oxymorphone solution $(0.1 \mathrm{ml}$ Numorphan in $2 \mathrm{ml}$ saline) was placed into the resulting cavity in the cord. The incision was closed, and the animal was allowed a 1-1.5 hour recovery period.

To test the hindlimb withdrawal reflex, the animal was first placed into a cloth restraint and suspended from parallel bars of a stereotaxic unit. A hip pin was inserted against each ileum ensuring pelvic stabilization. Stimulating electrodes (Teca MF-12 with $2 \mathrm{~mm}$ bared tips, TECA Corp., Pleasantville, NY) were inserted subcutaneously into the dorsum of the left hindpaw and secured with tape. Recording electrodes (Teca MF-12, $2 \mathrm{~mm}$ bared tips) were placed into the left biceps femoris muscle and connected to a differential amplifier (Grass, Quincy, MA; P5 series). A grounding electrode was inserted into the dorsal musculature. The left hindpaw was then attached to a force-displacement transducer (Grass FT03C), and $75 \mathrm{~g}$ of tension was applied. A Grass S88 stimulator, in series with a Grass stimulus isolation unit (S1U5) and a Grass constant current unit (CCU1A), delivered electrical pulses (pulse rate $500 / \mathrm{sec}$, pulse duration $0.1 \mathrm{~ms}$, train duration $5 \mathrm{~ms}$, train rate $1 / 30 \mathrm{sec}$ ) to the hindpaw. Signals from the force transducer (early and late components of reflex) and the differential amplifier (reflex evoked muscle potentials) were sent both to a storage oscilloscope (Tektronix, Beaverton, OR; model 2230) and to a Hewlett-Packard FM analog tape recorder for data storage. After initial testing to determine whether electromyogram. (EMG) and force potentials were present and relatively free of noise, reflex testing was begun, using the constant current unit to increase the stimulus intensity incrementally from 0.25 to $15.0 \mathrm{~mA}$. Testing was performed 15 minutes after administration of pargyline (monoamine oxidase inhibitor, $6.25 \mathrm{mg}$ i.p.) and again 15 minutes after administration of LDOPA (Sigma, $6.25 \mathrm{mg}, 50 \%$ i.m., 50\% i.v.). At each stimulus level, the reflex evoked EMG activity and force components were recorded and stored for subsequent analysis. The 15 minute period between drug administration and testing was to ensure that effective blood levels of the drugs had been reached. After the administration of L-DOPA, the animals exhibited peripheral autonomic signs indicative of catecholamine release, such as piloerection, exopthalamos, excessive salivation, and sometimes urination.

\section{Histochemical analysis}

\section{Glyoxylic acid technique}

Following reflex testing, the rat was deeply anesthetized by an injection of ketamine and xylazine. The spinal cord (T11-L5) was quickly removed and frozen. The freezing technique employed a mixture of liquid propane and ethane $(5: 1)$ cooled by liquid nitrogen. The specimen was placed in a holder containing O.C.T. compound (Tissue-Tek, Miles, Inc., Elkhart, IN) and dipped quickly into the propane and ethane for 20 seconds. Once frozen, the specimen was stored at $-70^{\circ} \mathrm{C}$ until sectioning.

Ten micrometer thick longitudinal sections of each specimen were placed on coverglasses and allowed to dry. The coverglasses were dipped into a glyoxylic acid solution three times and then dried under a blow dryer for fifteen minutes $/ 18 /$. The sections were heated in a $95^{\circ} \mathrm{F}$ oven for 3.5 minutes and examined using an Olympus IMT2 microscope equipped for epifluorescence $(390 \mathrm{~nm}$ excitation wavelength).

\section{Immunocytochemical methods}

Cell cultures were fixed with $4 \%$ paraformaldehyde in $0.1 \mathrm{M}$ phosphate buffer. Chromaffin cells were identified using antibodies against tyrosine hydroxylase (TH) (Eugene Tech, Allendale, NJ) and a Vectastain Elite kit (Vector Labs, Burlingame, CA). Briefly, fixed cells were rinsed several times with phosphate buffered saline (PBS) plus $0.5 \%$ Triton X-100. Goat serum (1\%) was added for 20 minutes as a blocking agent. TH antibody (1:2000 dilution) was incubated overnight on a shaker table at $12^{\circ} \mathrm{C}$. After rinsing, biotinylated secondary antibody (Vector) was added for 30 minutes. $A B C$ reagent (Vector) was added for another 30 minutes. Visualization was accomplished using diaminobenzidine (DAB) (Polysciences, Warrington, PA).

The monoclonal antibody $217 \mathrm{c}$ (courtesy of de Vellis) was used to identify Sc cells $/ 24 /$. The cells were incubated with the antibody at a dilution of 1:500. A Vectastain Elite kit provided reagents 
necessary for proper labelling. The steps followed were similar to those outlined above for AM cells.

\section{Cryoculture techniques}

Frozen sections $(10 \mu \mathrm{m})$ of normal rat adult spinal cord were placed in the wells of glass coverslip dishes. The dishes were stored overnight at $-20^{\circ} \mathrm{C}$ The following day they were rinsed with DMEM growth medium several times before addition of rat AM cells. After the last rinse with DMEM growth medium, high NGF growth medium was added to the plates. The AM cells were added by dropping a high density cell suspension from a pipet tip directly above each section. The plates were not moved for approximately 24 hours, giving the cells time to become firmly attached to the tissue. Three to five days after plating, the cells were fixed with $4 \%$ paraformaldehyde in phosphate buffer. The cells were then labelled using the techniques for $\mathrm{TH}$ antibody labelling outlined above.

\section{Data analysis}

Averaged maximum reflex-evoked force data from one group were compared to force data from another group by using the Mann-Whitney $U$ statistical test.

\section{RESULTS}

\section{Histology}

\section{Dissociated cells in vitro}

Chromaffin cells were grown on collagen in the presence of NGF. The AM cells in culture with NGF developed extensive processes in three to five days which were positive for anti-TH antibody (Figure 2A). Schwann cell cultures were positively labelled immunocytochemically with the antibody 217c after 1-3 days in culture (Figure 2B). Cells from the samples of leftover cell suspension from both the AM and Sc implants grew processes within three days after replating.

\section{AM cells on spinal cord in vitro}

Staining the cryocultures with anti-TH antibody 3-5 days after plating showed that the majority of AM cells adhered to the gray matter of the spinal cord sections (Figure 3). Few AM cells extended processes onto the gray or white matter of the cord. A count of the anti-TH labelled AM cells on 12 randomly selected sections of spinal cord revealed that only 125 of the 609 cells counted $(20.5 \%)$ attached to the white matter of the cord. By contrast, AM cells expressing the neuronal phenotype grew extensively on the untreated glass coverslip around each section.

\section{Implant cells in vivo}

Catecholamine-producing cells were present in the spinal cords of all animals that received AM cell implants (Figure 4). The surviving AM cells were well integrated into the parenchyma of the spinal cord. Brightly fluorescing CA cells were visible, predominantly in the left ventral region of the cords, but also along the needle tracts. Cells were typically found either in lines (Fig. 4A) or small clusters (Fig. 4B). The CA cells appeared to migrate both craniad and caudad from the injection sites. Short processes emerged from a small number of the AM cells. No CA fluorescence was observed in spinal cord tissue taken from lesioned $(n=1)$, control $(n=1)$, or Sc cell $(n=2)$ implanted animals.

\section{Reflex testing}

\section{Control rats}

Upon electrical stimulation of the dorsum of the hindpaw, SLCs were recorded from the ipsilateral biceps femoris muscle of control animals (Figure 5A,B). This withdrawal response was characteristically short in duration, as shown by the EMG. and produced only a small amount of force. LLCs were evoked in control animals only after the administration of L-DOPA (Figure 5C, D). Electrical stimulation after L-DOPA resulted in a large amplitude, long duration EMG response concomitant with the production of a vigorous flexion (average maximum force $=764 \pm 58.8 \mathrm{~g}$ $(\mathrm{SD}), \mathrm{n}=5$ ) (Figure 6)

\section{6-OHDA lesioned (no-implant) rats}

SLCs were also evoked by electrical stimulation 1.1 all lesioned animals prior to administration of $\mathrm{L}$ DOPA. In a few of the lesioned rats (2/7), small LLCs were also evoked by these initial stimulations. After administration of L-DOPA, stimulation 


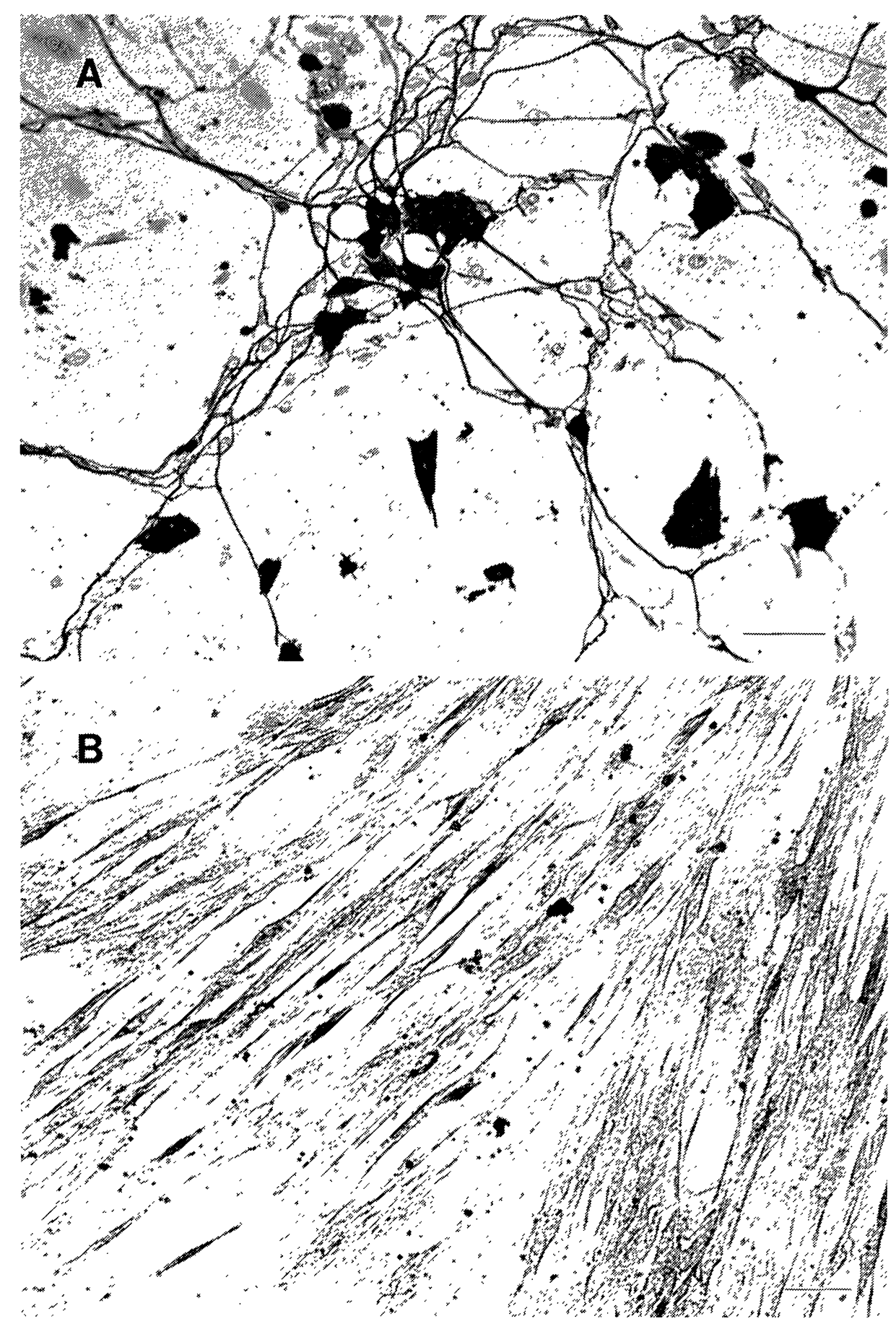

Fig. 2: Phase contrast photographs of chromaffin cells (A) and Schwann cells (B) in vitro. Both cell types were plated from cell suspensions used for spinal implantation. After 4 days in culture, chromaffin cells were fixed and immunocytochemically stained using anti-TH antibody. Schwann cells were fixed and labelled with $217 \mathrm{c}$ antibody after 3 days in culture. Scale bars, $100 \mu \mathrm{m}$ (A); $50 \mu \mathrm{m}$ (B). 


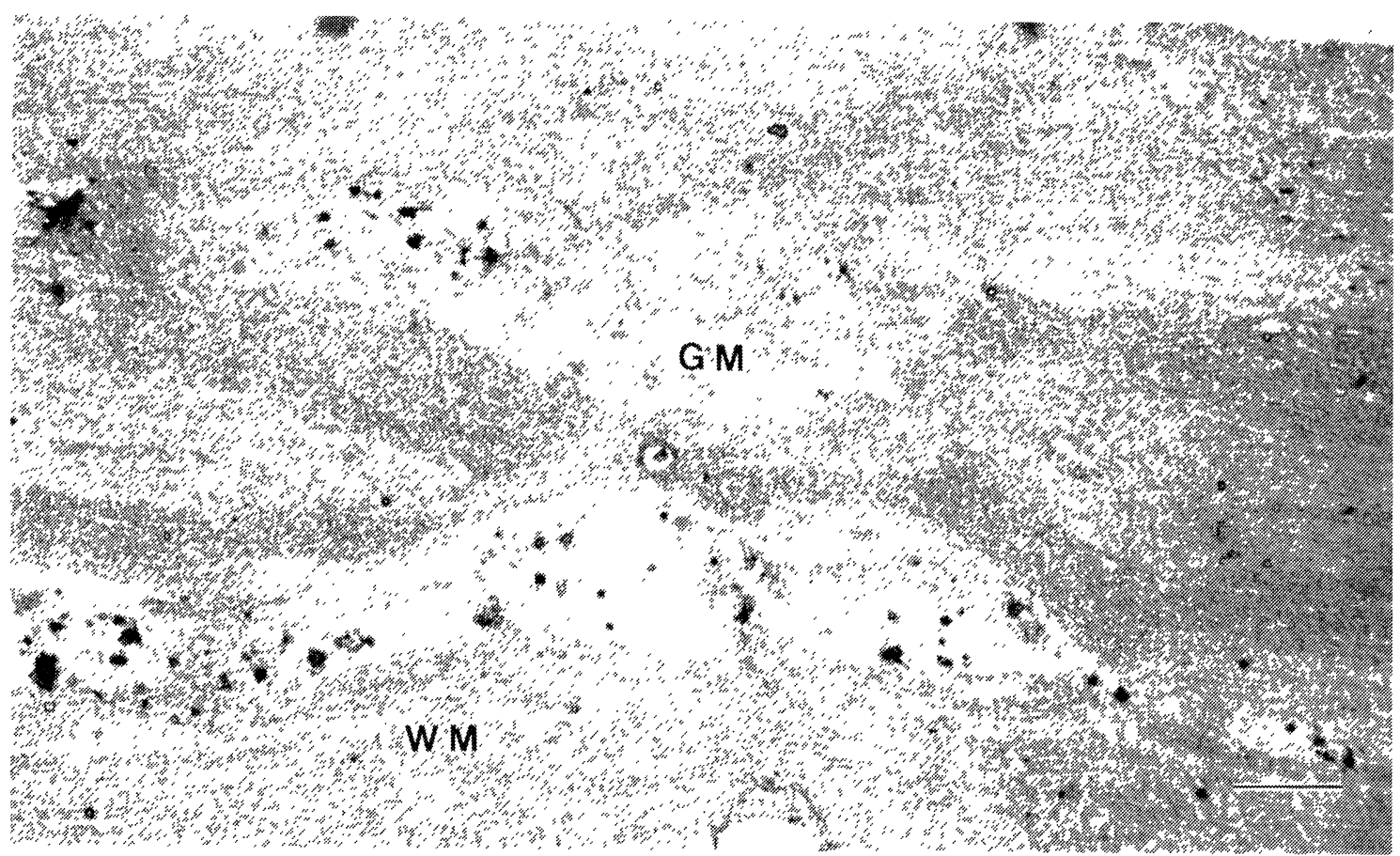

Fig. 3: Rat chromaffin cells were added to tissue culture dishes containing longitudinal sections of normal rat spinal cord. Threc to five days after plating, the cells were fixed and stained with anti-TH. Chromaffin cells (stained black) adhered to the gray matter (GM) of the cord, but not to the white matter (WM), and extended very few processes. Scale bar, $100 \mu \mathrm{m}$.

evoked LLCs in all rats (Figure 5E, F), but the force of the response in all cases was significantly $(\mathrm{p}<0.002)$ less than that of the control rats (avg maximum force $=93.7 \pm 47 \mathrm{~g}(\mathrm{SD}), \mathrm{n}=7$ ) (Figure 6). Stimulus-response curves for both the control and lesioned rats (post L-DOPA) showed a high degree of correlation ( $\mathrm{R}$ value $>0.9$ ) between stimulus strength and resultant withdrawal force

\section{Implanted rats}

Initially, and after pargyline administration, electrical stimulation of the hindpaw consistently elicited SLCs of the withdrawal reflex in all the implanted rats. This stimulus also resulted in the presence of small amplitude LLCs in many of these same animals. The maximal force generated by the Sc cell implanted rats upon stimulation showed only a modest increase after administration of L-DOPA (Figure 7B). The average maximal force evoked in Sc animals $(127.3 \pm 72.5 \mathrm{~g})$ was not significantly different from that of the lesioned rats $(93.7 \pm 47 \mathrm{~g})$ by the Mann-Whitney U statistical test (Figure 6) AM cell implanted rats produced a significantly greater amount of force of withdrawal upon hindpaw stimulation (average force $=394.7 \pm 118$ g) than did Sc implanted controls or no-implant control rats ( $p<0.001, p<0.0006$, respectively) (Figure 7D). There was an increased amount of spontaneous EMG activity, both before and subsequent to stimulation of the paw, in rats implanted with AM cells (Figure 7C). The average correlation coefficient was very close to 0.9 for the post L-DOPA stimulus-response curves of both implant groups.

\section{DISCUSSION}

In this study we found that implanting cultured neonatal chromaffin cells into lesioned spinal cords partially restored a specific reflex (hindlimb withdrawal). 

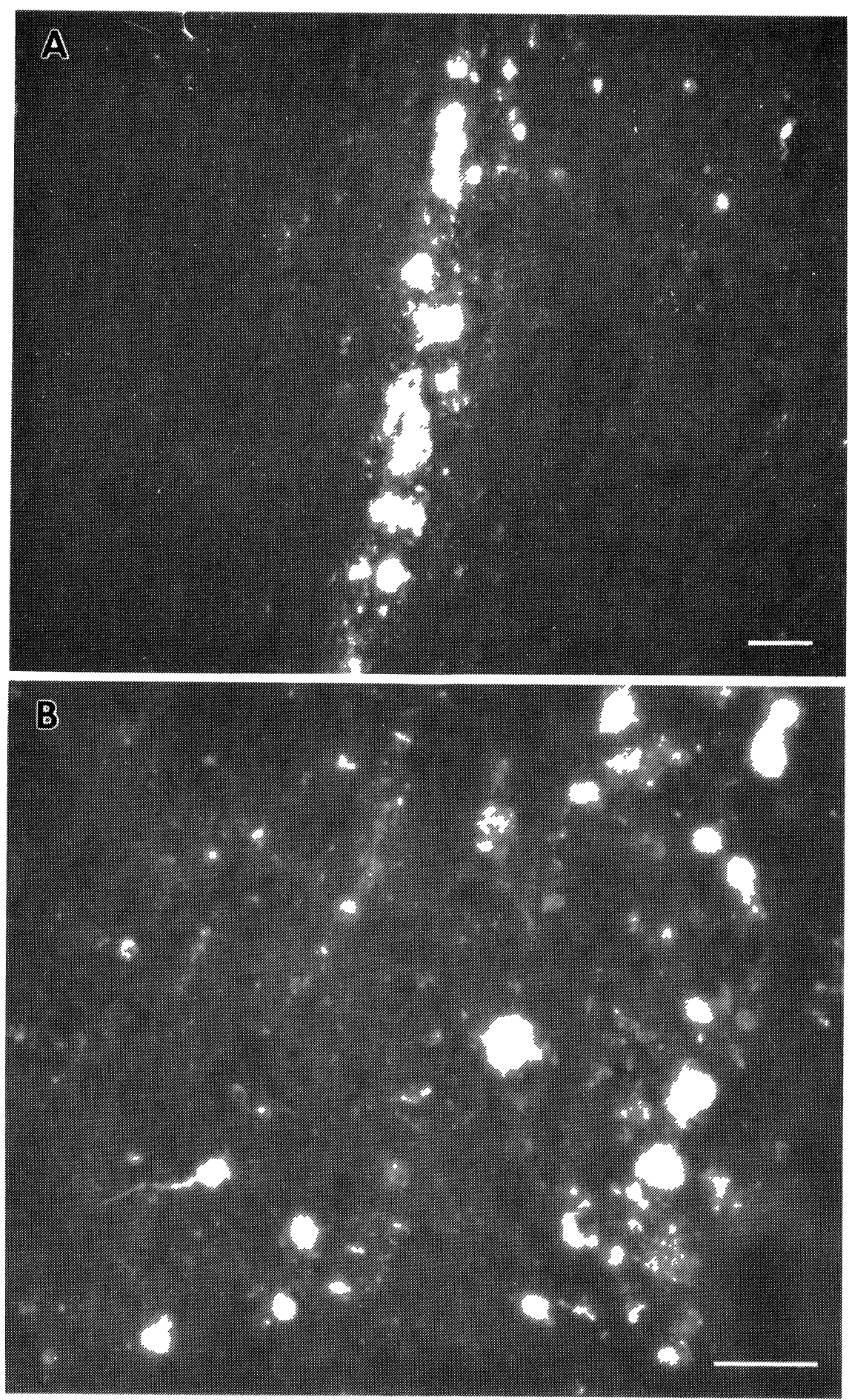

Fig. 4: Implant sites in the spinal cords of 2 rats that received injections of AM cells. Three months post implantation, spinal cords were removed, frozen, and longitudinally sectioned. The glyoxylic acid technique for catecholamine histofluorescence was used to label the spinal cord sections. Green fluorescing cells were found along needle tracks (A) or in small clusters (B) in the ventral region of the cords. In a few cases the cells extended short processes. Scale bars, $100 \mu \mathrm{m}(\mathrm{A}) ; 50 \mu \mathrm{m}(\mathrm{B})$. 
A

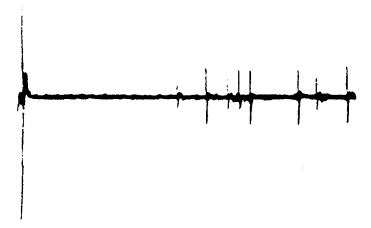

C

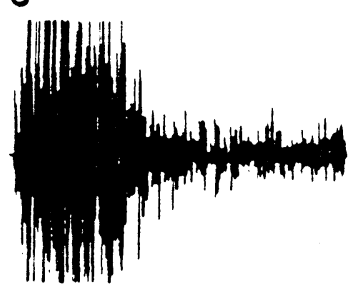

E

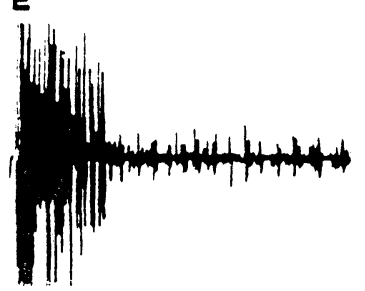

B

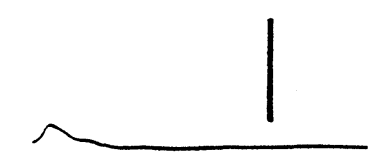

D

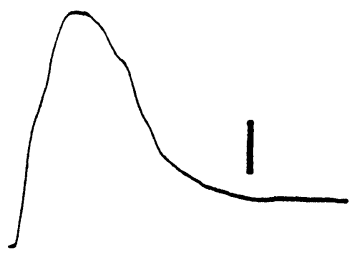

$\boldsymbol{F}$

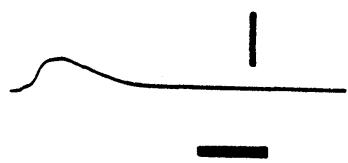

Fig. 5: Representative electromyogram (EMG) activity (A, $C, E)$ and force production $(B, D, F)$ recorded during the hindlimb withdrawal reflex after electrical stimulation (@15 mA) of the hindpaw. The hindlimb withdrawal reflex is composed of a short latency component (SLC) prior to L-DOPA administration (A, B). After L-DOPA, electrical stimulation results in a large amplitude, long latency component (LLC) in control animals (C, D), which usually masks the SLC. EMG activity and force production are correlated to stimulus strength. Catecholamine denervation (using 6OHDA) of the spinal cord causes a marked reduction in the withdrawal reflex LLC $(E, F)$. Each EMG and evoked potential represents $500 \mathrm{~ms}$ of post-stimulus recording. Vertical bars, $190 \mathrm{~g}$; horizontal bar, $100 \mathrm{~ms}$.

Reflex activity in implanted animals was tested after 3 months in this study. Moorman's work /35/ revealed that cells could survive in the spinal cord for a period of 4 months, though more cells were present at 2 months. Since the ultimate aim of this study is to develop procedures that could aid neurologically impaired patients, longer term effects

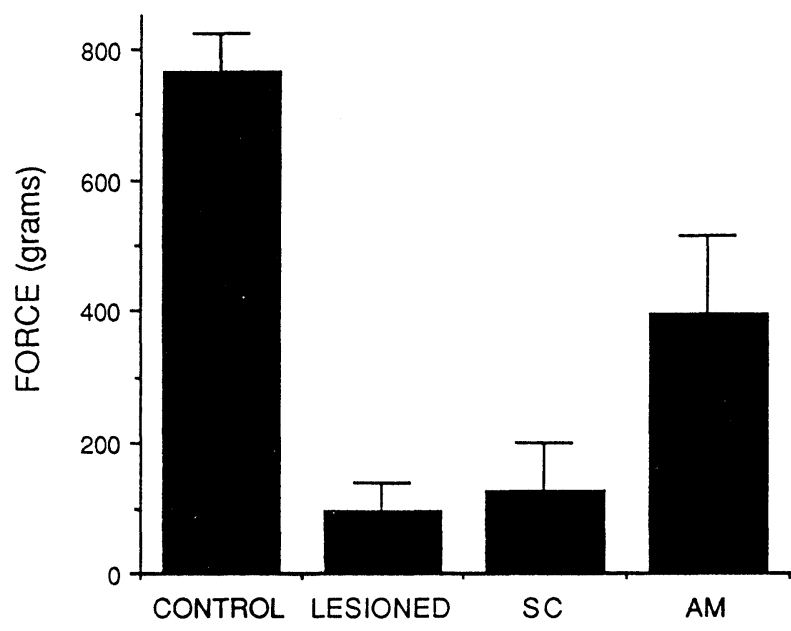

Fig. 6: Histogram showing the average maximum force produced during the LLC of the withdrawal reflex after L-DOPA administration by each experimental group. The chromaffin cell (AM) implant rats produced significantly more force than did the lesioned or Schwann cell (Sc) implant animals, but significantly less force than the control rats. There was no statistical difference between lesioned and Sc cell implant rats.

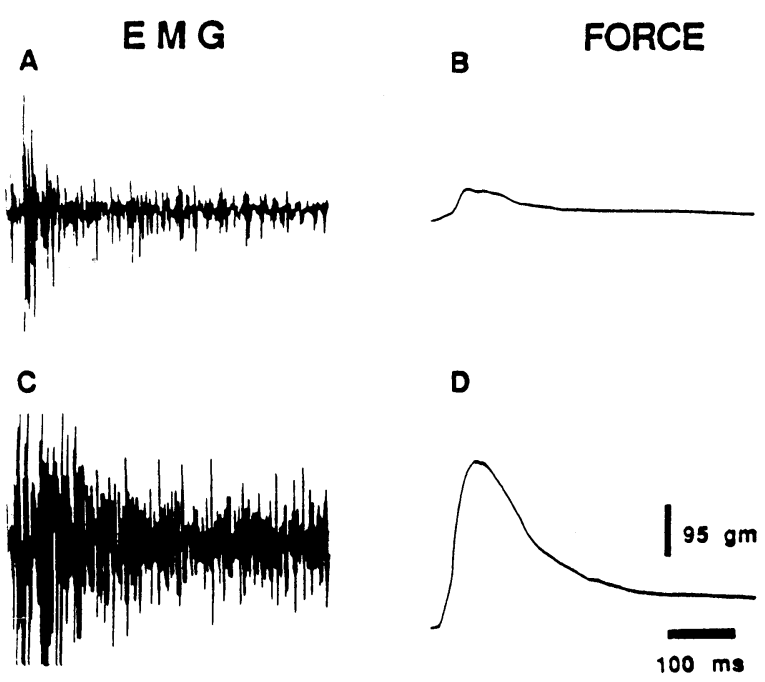

Fig. 7: Representative EMG activity $(A, C)$ and force production $(B, D)$ recorded during the hindlimb withdrawal reflex in animals implanted with Schwann cells (Sc) (A, B), or adrenal medullary cells $(A M)(C, D)$. Rats implanted with AM cells had significantly more forceful reflex responses (@) $15 \mathrm{~mA}$ stimulus) and an increased amount of spontaneous EMG activity after administration of L-DOPA compared to rats implanted with Sc cells. Each EMG and evoked potential represents $500 \mathrm{~ms}$ of post-stimulus recording. Vertical bar, $95 \mathrm{~g}$; horizontal bar, $100 \mathrm{~ms}$. 
of the implants on reflex activity are of interest. Therefore, we chose a time point that was modestly long-term yet one at which we could be confident that cells would still be present in the cord.

Plating of chromaffin cells on longitudinal sections of spinal cord in vitro revealed an apparent preference of the AM cells (79.5\%) for the gray matter of the cord. Cells attached to and survived upon gray matter, but very few of these cells extended processes. Far fewer AM cells (20.5\%) attached to white matter regions of these sections. The potential of AM cells to grow in this in vitro environment was apparent because cells growing upon the untreated coverglass in these cultures extended many long processes. The white matter of adult rat spinal cord inhibits neuronal attachment and neurite outgrowth. Dorsal root ganglion and hippocampal neurons, plated onto cryostat sections of adult spinal cord, attach to and extend processes on gray matter but do not extend processes on regions of white matter $/ 13,16,17 /$. A protein found in association with oligodendrocytes in CNS white matter inhibits neurite outgrowth /44,45/. Many elements of an in vivo spinal cord environment are obviously absent in these previously frozen sections, but the results indicate that factors present in the spinal cord which inhibit outgrowth from several types of neurons also inhibit the outgrowth of neurites from AM cells. Similar inhibition of outgrowth is seen when chromaffin cells are implanted into various regions of the brain, including the ventricles /39/. When locus ceruleus neurons are implanted into the spinal cord, outgrowth from the implanted neurons occurs primarily in the gray matter $/ 38 /$. Because implanted chromaffin cells extend very few, if any, processes, the recovery of reflex activity associated with AM cell implants may result from an endocrine-like release of NA rather than from synaptic interaction between implanted cells and host spinal cord interneurons.

Animals that received 6-OHDA induced spinal cord lesions produced, on average (after L-DOPA administration), only $12 \%$ of the force of withdrawal generated by control rats at maximal stimulus levels. This demonstrates that catecholamine fibers within the spinal cord are an important component of this reflex and that subdural injection of 6-OHDA is an effective means of reducing this component. A study by Berge $/ 5 /$ demonstrated that approximately $90 \%$ of the noradrenaline fibers in the lumbar spinal cord are destroyed following intrathecal administration of 6-OHDA. The small amount of LLC activity which was present in a number of lesioned animals 3 months after the lesion may have been due to the presence of ceruleospinal fibers not destroyed by the 6-OHDA injection. Some CA fibers may have remained in the 6-OHDA lesioned implant rats also. However, the amplitude of the LLCs recorded in the AM implanted rats was significantly larger than the amplitude of the LLCs recorded in lesioned rats $(p<0.0006, p<0.002$, respectively) (Figure 7 ). Therefore, incomplete destruction of the spinal cord CA fibers, if it did occur, had no significant effect on our results. Implanting Sc cells alone did not aid in recovery of the reflex; consequently, non-specific effects from implanting nervous system cells into the spinal cord were not responsible for the observed functional recovery. Several lines of evidence support dependence of the LLC on the release of NA in the spinal cord. The effects of LDOPA on the LLC are reversed by adrenergic $\alpha$ receptor blocking agents but are not reversed by $\beta$ receptor blocking agents /34/. Reserpine (which blocks the formation of NA but not dopamine) prevents the expression of the LLC pathway. After inhibition of dopamine- $\beta$-hydroxylase and depletion of pre-existing NA stores, L-DOPA does not allow induction of activity in the LLC pathway /31/. Previous work from our laboratories $/ 35 /$ has shown that phentolamine, an adrenergic $\alpha$-receptor blocker, completely inhibits the production of the LLC (after L-DOPA) in animals with NA releasing implants and that clonidine, an adrenergic $\alpha$ receptor agonist, facilitates production of a LLC after activation of FRAs. Thus, the reappearance of a LLC after L-DOPA administration in animals with AM implants suggests release of NA from the surviving implanted cells.

Glyoxylic acid staining revealed the presence of CA-containing fluorescent cells at injection sites of rats implanted with AM cells. The color of the fluorescence (green) indicated that these cells were CA-containing $122,49 /$. The diameter of the fluorescent cell bodies ranged from 15-35 $\mu \mathrm{m}$, which correlates well with our measurements of AM cells in vitro, and with measurements from 
other studies $/ 19,37 /$. Similarly, fluorescent cells were not observed in spinal cords from lesioned or Sc implanted animals after glyoxylic acid staining, which supports our belief that the glyoxylic acid technique specifically identified implanted AM cells.

In this investigation we demonstrated that cultured neonatal chromaffin cell implants are able to survive for 3 months in the rat spinal cord and are as effective as fetal tissue implants at restoring hindlimb withdrawal reflex function. Future directions of research in this area include testing the effects on the reflex of implanting NA-producing cell lines, such as PC 12 cells $/ 28 /$, into the spinal cord or implanting osmotic pumps into lesioned rats which would release NGF into the site of the AM cell implant.

\section{ACKNOWLEDGEMENTS}

This work was supported by a grant from the American Paralysis Association. The excellent technical work of Joel Zupnik is gratefully acknowledged. We also thank Jean de Vellis for the $217 \mathrm{c}$ antibodies used in this study.

\section{REFERENCES}

1. Agnati LF, Zini I, Zoli M, Fuxe K, Merlo Pich E, Grimaldi R, Toffano G, Goldstein M. Regeneration in the central nervous system: Concepts and facts. Adv and Technical Standards in Neurosurg 1988; 16: 3-50.

2. Aguayo AJ, David S, Richardson P, Bray G. Axonal elongation in peripheral and central nervous system transplants. Adv Cellular Neurobiol 1982; 3: 215-234.

3. Anden NE, Jukes MGM, Lundberg A, Vyklicky L. The effect of DOPA on the spinal cord: Influence on transmission from primary afferents. Acta Physiol Scand 1966; 67: 373-386.

4. Barnes CD, Fung SJ, Pompeiano O. Descending catecholaminergic modulation of spinal cord reflexes in cat and rat. Ann NY Acad Sci 1989; 563: 45-58.

5. Berge O-G, Fasmer OB, Tveiten L, Hole K. Selective neurotoxic lesions of descending serotonergic and noradrenergic pathways in the rat. J Neurochem 1985; 44: 1156-1161.

6. Bernstein JJ, Goldberg WJ. Maintenance of host medullary nucleus gracilis neurons after C3 homografting of fetal spinal cord into host fasciculus gracilis. Brain Res 1989; 488: 180-185.

7. Björklund A, Skagerberg G. Descending monoaminergic projections to the spinal cord. In: Sjolund B,
Björklund A, eds, Brainstem Control of Spinal Mechanisms. Amsterdam: Elsevier Biomedical Press, 1982; 55-87.

8. Borgens RB, Blight AR, Murphy DJ, Stewart L. Transected dorsal column axons within the guinea pig spinal cord regenerate in the presence of an applied electric field. J Comp Neurol 1986; 250: 168-180.

9. Bracken MB, Shepard MJ, Collins WF, Holford TR, Young W, et al. A randomized controlled trial of methylprednisolone or naloxone in the treatment of acute spinal cord injury. New Engl J Med 1990; 322: 1405-1411.

10. Braughler JM, Hall ED. Effects of multi-dose methylprednisolone sodium succinate administration on injured cat spinal cord neurofilament degradation and energy metabolism. J Neurosurg 1984; 61: 290295.

11. Buchanan JM, Nornes HO. Transplants of embryonic brainstem containing the locus ceruleus into spinal cord enhance the hindlimb flexion reflex in adult rats Brain Res 1986; 381: 225-236.

12. Carew TJ. The control of reflex action. In: Kandel ER, Schwartz JH, eds, Principles of Neural Science. New York: Elsevier, 1985; 457-468.

13. Carpenter MK, Hassinger TD, Whalen LR, Kater SB. CNS white matter can be altered to support neuronal outgrowth. J Neurosci Res 1994; 37: 1-14.

14. Commissiong JW. Development of catecholaminergic nerves in the spinal cord of the rat. Brain Res 1983; 264: 197-208.

15. Commissiong JW. Fetal locus ceruleus transplanted into the transected spinal cord of the adult rat. Brain Res 1983; 271: 174-179.

16. Crutcher KA. Tissue sections from the mature rat brain and spinal cord as substrates for neurite outgrowth in vitro: Extensive growth on gray matter but little growth on white matter. Exp Neurol 1989; 104: $39-54$

17. Crutcher KA, Privitera M. Axonal regeneration on mature human brain tissue sections in culture. Ann Neurol 1989; 26: 580-583.

18. de la Torre JC, Surgeon JW. A methodological approach to rapid and sensitive monoamine histofluorescence using a modified glyoxylic acid technique: The SPG method. Histochemistry 1976; 49: 81-93.

19. Doupe AJ, Landis SC, Patterson PH. Environmental influences in the development of neural crest derivatives: Glucocorticoids, growth factors, and chromaffin cell plasticity. J Neurosci 1985; 5: 2119 2142.

20. Ellis W. Pulsed subcutaneous electrical stimulation in spinal cord injury: Preliminary results. Bioelectromagnetics 1987; 8: 159-164.

21. Faden AI, Jacobs TP, Smith MT, Holaday JW. Comparison of thyrotropin-releasing hormone (TRH), naloxone, and dexamethasone treatments in

JOURNAL OF NEURAL TRANSPLANTATION \& PLASTICITY 
experimental spinal cord injury. Neurology $1983 ; 33$ 673-678.

22. Felten DL, Felten SY, Sladek JR, Notter MD, Carlson SL, Bellinger DL, Wiegand SJ. Fluorescence histochemical techniques for catecholamines as tools in neurobiology. J Microsc 1990; 157: 271-283.

23. Ferencsik M, Garay K, Mihaly A, Csillik B. Cobalt complex ATP enhanced regeneration in the dorsal horn of the rat spinal cord. Exp Brain Res 1990; 76: 409-416

24. Fields KL, Dammerman M. A monoclonal antibody equivalent to anti-rat neural antigen-1 as a marker for Schwann cells. J Neurosci 1985; 15: 877-885.

25. Foster GA, et al. Transmitter expression and morphological development of embryonic medullary and mesencephalic raphe neurons after transplantation to the adult rat central nervous system. Exp Brain Res $1985 ; 60: 427-444$

26. Gelderd JB. Evaluation of blood vessel and neurite growth into a collagen matrix placed within a surgically created gap in rat spinal cord. Brain Res 1990; 511: 80-92.

27. Goldberg WJ, Bernstein JJ. Transplant derived astrocytes migrate into host lumbar and cervical spinal cord after implantation of E14 fetal cerebral cortex into adult thoracic spinal cord. J Neurosci Res 1987; 17: 391-403.

28. Greene LA, Tischler AS. Establishment of a noradrenergic clonal line of rat adrenal pheochromocytoma cells which responds to nerve growth factor. Proc Natl Acad Sci USA 1976; 73: 2424-2428.

29. Hoerlein BF, Redding RW, Hoff EJ, McGuire JA. Evaluation of dexamethasone, DMSO, mannitol, and solcoseryl in acute spinal cord trauma. J Am Animal Hosp Assoc 1983; 19: 216-226.

30. Jankowska E, Jukes MGM, Lund S, Lundberg A. The effect of DOPA on the spinal cord: 6. Half center organization of interneurons transmitting effects from the flexor reflex afferents. Acta Physiol Scand 1967; 70: 389-402.

31. Jurna I, Lundberg A. The influence of an inhibitor of dopamine beta hydroxylase on the effect of DOPA on transmission in the spinal cord. In: Von Euler C, Skoglund S, Söderberg U, eds, Structure and Functions of Inhibitory Neuronal Mechanisms. Oxford Pergamon Press, 1968; 469-472.

32. Kao CC, Chang LW, Bloodworth JMB. Axonal regeneration across transected mammalian spinal cords: an electron microscopic study of delayed microsurgical nerve grafting. Exp Neurol 1977; 54 591-615.

33. Lundberg A. Multisensory control of spinal reflex pathways. In: Ganit R, Pompeiano O, eds, Reflex Control of Posture and Movement. Progress in Brain Research. Amsterdam: Elsevier/North Holland Biomedical Press, 1979; 50: 11-28.

34. Lundberg A. Inhibitory control from the brain stem of

VOLUME 5, NO. 2, 1994 transmission from primary afferents to motoneurons, primary afferent terminals and ascending pathways. In: Sjolund B, Björklund A, eds, Brain Stem Control of Spinal Mechanisms. Amsterdam: Elsevier Biomedical Press, 1982; 179-224.

35. Moorman SJ, Whalen LR, Nornes HO. A neurotransmitter specific functional recovery mediated by fetal implants in the lesioned spinal cord of the rat. Brain Res 1990; 508: 194-198.

36. Muller TH, Unsicker $\mathrm{K}$. Nerve growth factor and dexamethasone modulate synthesis and storage of catecholamines in cultured rat adrenal medullary cells: Dependence on postnatal age. J Neurochem 1986; 46: 516-524.

37. Nishino HT, Ono $T$, Shibata R, et al. Grafted rat adrenal medullary cells: Structural and functional studies. Prog Brain Res 1988; 78: 521-525.

38. Nornes HO, Björklund A, Steveni U. Reinnervation of the denervated adult spinal cord of rats by intraspinal transplants of embryonic brain stem neurons. Cell Tissue Res 1983; 230: 15-35.

39. Perlow MJ, Jumakura K, Guidotti G. Prolonged survival of bovine adrenal chromaffin cells in rat cerebral ventricles. Proc Natl Acad Sci USA 1980; 77: 5278-5281.

40. Puchala E, Windle WF. The possibility of structural and functional restitution after spinal cord injury. A review. Exp Neurol 1977; 55: 1-42.

41. Richardson PM, Verge Issa VMK, Riopelle RJ. Distribution of neuronal receptors for nerve growth factor in the rat. J Neurosci 1986; 6: 2312-2321.

42. Sagen J, Pappas GD, Perlow MJ. Adrenal medullary tissue transplants in the rat spinal cord reduce pain sensitivity. Brain Res 1986; 384: 189-194.

43. Sagen J, Pappas GD. Morphological and functional correlates of chromaffin cell transplants in CNS pain modulatory regions. Ann NY Acad Sci 1987; 495: 306-333.

44. Schnell L, Schwab ME. Axonal regeneration in the rat spinal cord produced by an antibody against myelinassociated neurite growth inhibitors. Nature 1990; 343 : 269-272.

45. Schwab ME, Caroni P. Oligodendrocytes and CNS myelin are nonpermissive substrates for neurite growth and fibroblast spreading in vitro. J Neurosci 1988; 8: 2381-2393.

46. Shelton DL, Reichardt LF. Studies on the expression of the $\beta$ nerve growth factor (NGF) gene in the central nervous system: Level and regional distribution of NGF mRNA suggest that NGF functions as a trophic factor for several distinct populations of neurons. Proc Natl Acad Sci USA 1986; 83: 2714-2718.

47. Sieradzan K, Vrbova G. Replacement of missing motoneurons by embryonic grafts in the rat spinal cord. Neuroscience 1989; 31: 115-130.

48. Swanson LW. The locus ceruleus: A cytoarchitectonic, golgi, and immunohistochemical study in the albino rat. Brain Res 1976; 110: 39-56. 
49. Unsicker K, Krisch B, Otten U, Thoenen H. Nerve growth factor-induced fiber outgrowth from isolated rat adrenal chromaffin cells: Impairment by glucocorticoids. Proc Natl Acad Sci USA 1978; 75: 34983502 .

50. Unsicker K. Differentiation and phenotypical conversion of adrenal medullary cells: The effects of neuronotrophic, neurite promoting, hormonal and neuronal signals. In: Panula P. Paivarinta $\mathrm{H}$, Soinila S, eds, Neurohistochemistry: Modern Methods and Applications. New York: Alan R. Liss, Inc., 1986; 183-206. 

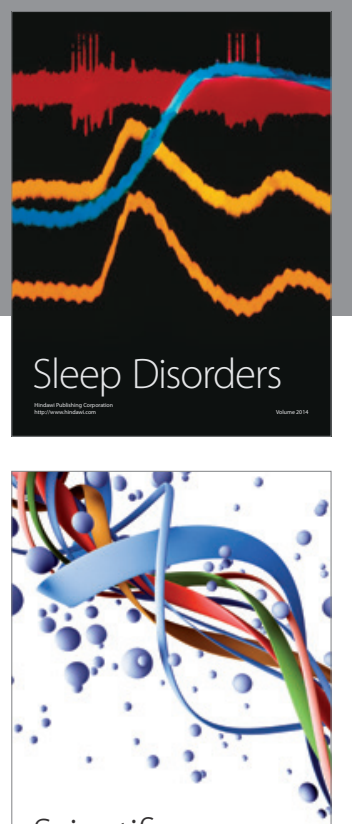

Scientifica
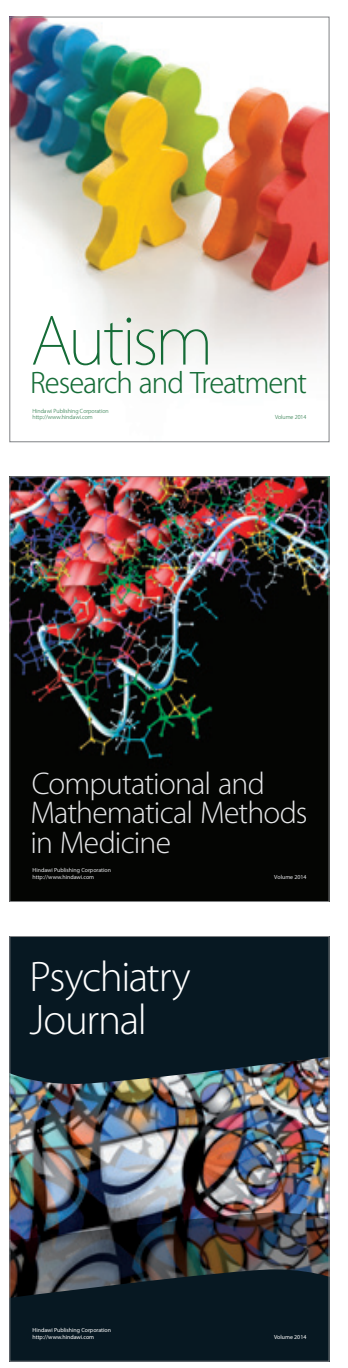
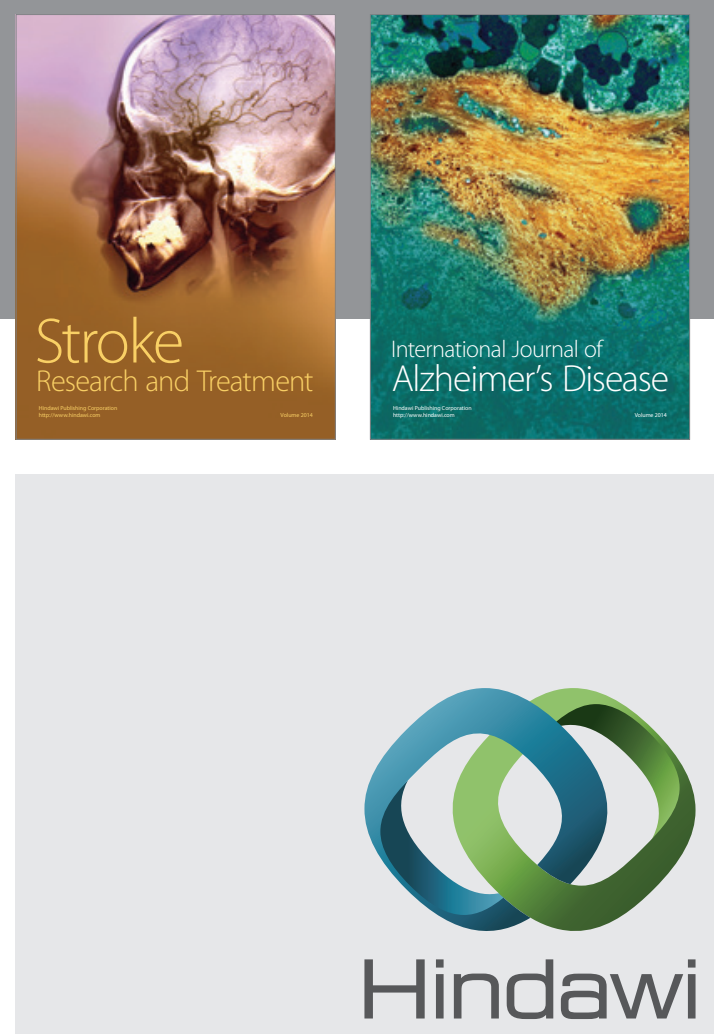

Submit your manuscripts at

http://www.hindawi.com
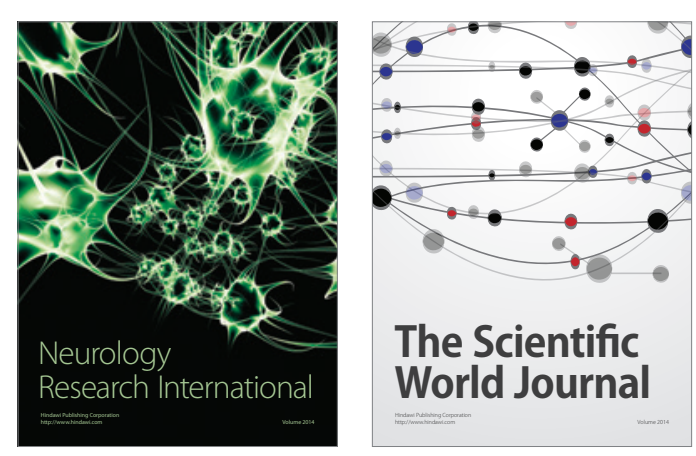

The Scientific World Journal

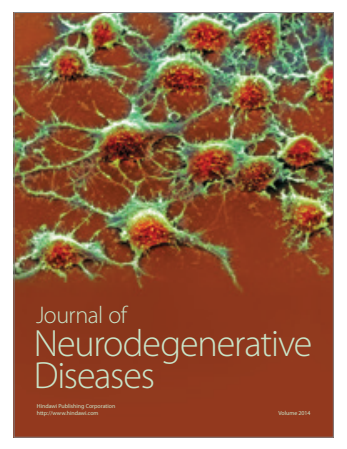

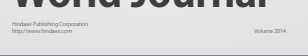

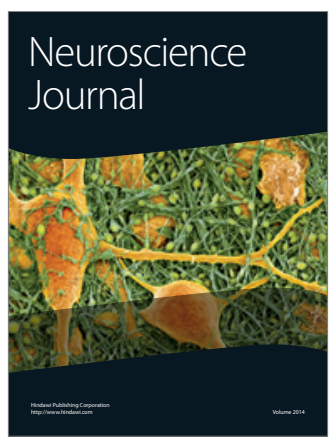

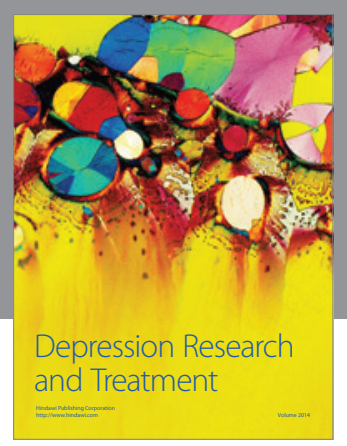
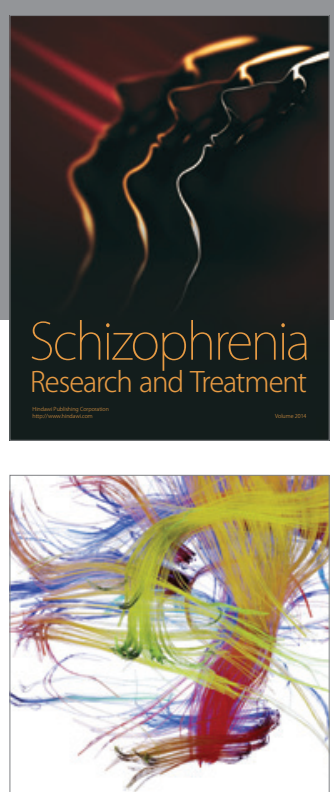

Brain Science

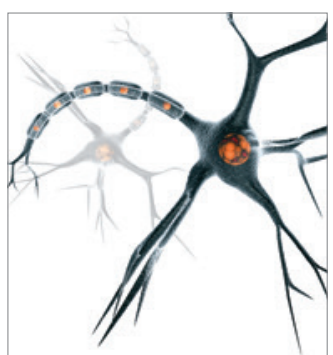

Neural Plasticity
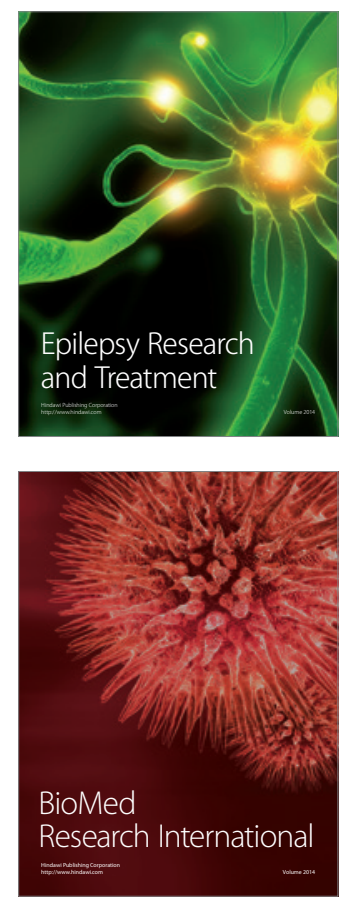

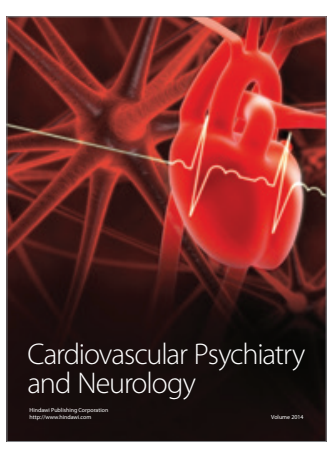

Parkinson's

Disease
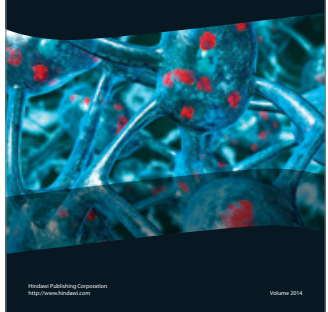